\title{
Successful detection of pathogenic Shiga-toxin-producing Escherichia coli in shellfish, environmental waters and sediment using the ISO/TS-13136 method
}

\author{
Baliere Charlotte ${ }^{1}$, Rince A. ${ }^{2}$, Thevenot D. ${ }^{3}$, Gourmelon Michele ${ }^{1,{ }^{*}}$
}

${ }^{1}$ Unité SG2M, Département RBE, Laboratoire Santé Environnement et Microbiologie, IFREMER, Plouzané, France

${ }^{2}$ UCBN, U2RM Stress/Virulence EA4655, Normandie-Université, Caen, France

${ }^{3}$ Laboratoire LMAP-LNR, UMR5557/Equipe 6, Marcy-L'Etoile, France

*Corresponding author : Michèle Gourmelon, email address : $\underline{\text { Michele.Gourmelon@ifremer.fr }}$

\begin{abstract}
:
The presence of highly pathogenic Shiga-toxin-producing Escherichia coli (STEC) in shellfish, upstream waters and sediment from coastal shellfish sites was evaluated using the ISO/TS-13136 method. Shellfish (oysters, mussels and cockles), water and sediment samples were collected monthly over a period of 1 year. The method used real-time PCR detection of stx1, stx2 and eae genes and genetic markers corresponding to the five major serogroups (O157, O26, O103, O111 and O145) on enrichment broths and the identification of STEC when these genes and markers were detected. stx genes were detected in the broth of $33 \%$ of shellfish batches $(n=126), 91 \%$ of water samples $(n=117)$ and $28 \%$ of sediment $(n=39)$. One stx1+, eae+ O26:H11 strain was isolated from a shellfish batch, and O26:H11, O145:H28 and O103:H2 strains without the stx gene $(n=9)$ were isolated from shellfish and waters. In conclusion, this study shows the suitability of the ISO/TS-13136 method to assess the presence of highly pathogenic E. coli strains in shellfish farming areas. It also highlights a low prevalence of STEC and consequently suggests a reduced corresponding human health risk.
\end{abstract}

Keywords : eae, sediment, shellfish, Shiga-toxin-producing Escherichia coli, stx, water

\section{Significance and Impact of the Study}

(STEC) infections have been reported following ingestion of contaminated food or water or after bathing in contaminated waters. However, to date, few studies concerning their detection in coastal environment and shellfish have been reported. The aim of this work was to assess the presence of STEC in three shellfish-harvesting areas by the ISO/TS-13136 method, which has recently been used for STEC detection in food. 
Pathogenic Shiga-toxin-producing E. coli (STEC) may cause human illnesses such as haemorrhagic colitis and life-threatening haemolytic-uraemic syndrome. Although a wide range of serotypes have been implicated in human STEC infections, five major serotypes (O157:H7, O26:H11, O103:H2, O111:H8, and O145:H28) are responsible for the vast majority of sporadic cases and outbreaks in Europe (Beutin and Fach 2014). Pathogenic STEC are characterized by the production of Shiga-toxin, a bacteriophage-encoded cytotoxin (O’Brien et al. 1984) and, in addition, are often shown to produce attaching and effacing lesions on intestinal mucosa. This latter property is encoded by genes, including eae, grouped together in a pathogenicity island referred to as the "locus of enterocyte effacement" (Paton and Paton 1998). Human infection occurs through ingestion of contaminated food or water or by contact with animals. The main reservoir for STEC is domestic ruminants, especially cattle (Pradel et al. 2000). Other animals, such as sheep, goats, pigs, birds, other wild animals, as well as humans, can also harbour STEC (Gyles 2007). STEC contamination of the environment may occur through the spreading of livestock manure, animal waste on pastures, via wastewaters from slaughterhouses, from treatment plant effluents and by wildlife (Ogden, et al. 2001; Vernozy-Rozand et al. 2002; Loukiadis et al. 2006). Coastal environments, including shellfish, may therefore become contaminated with STEC. Because of their filterfeeding behaviour and because they are traditionally consumed raw or undercooked, shellfish may present a potential risk to public health (Potasman et al. 2002). However, to our knowledge, while they have previously been detected in shellfish, STECs have not yet been reported as being involved in shellfish-borne outbreaks (Guyon et al. 2000; Gourmelon et al. 2006).

To date, few studies concerning the detection and isolation of pathogenic STEC strains in coastal environments and shellfish have been reported and, of those that have, none has 
66 focused on the prevalence of the five major STEC serotypes. Recently, a horizontal PCR-

67 based method has been developed for the detection of STEC (including the five major 68 serotypes associated with human infection) in foods and animal feed. This method, 69 recommended by EFSA (2009), is described in the ISO-13136 Technical Specification 70 (ISO/TS-13136:2012). It has already been applied in France for monitoring control in minced 71 meat frozen beef (DGAL 2013) and to evaluate the prevalence of STEC from their 72 corresponding serotypes in cattle faeces (Bibbal et al. 2014).

73 The present study describes the first application of the ISO/TS-13136 protocol to shellfish, 74 environmental waters and sediment in order to evaluate the presence of highly-pathogenic 75 STEC in shellfish-harvesting areas. 


\section{Level of contamination in water and shellfish}

E. coli counts were determined for all shellfish and water samples. Widely varying E. coli concentrations were found in shellfish, with concentrations ranging from $<67$ to 71,000 per 100 g. Thirty-seven samples presented a concentration of less than or equal to 230 E. coli per 100 g, 64 contained between 230 and 4,600 E. coli per $100 \mathrm{~g}$ and 25 presented a concentration greater than 4,600. Among shellfish, cockles were the most contaminated (geometric mean of 2,440 E. coli per $100 \mathrm{~g}$ versus 1,070 for mussels, and 364 for oysters). In waters, E. coli concentrations ranged from $<38$ to 190,530 per $100 \mathrm{ml}$, with a geometric mean of 1,224.

\section{Detection of stx1, stx2 and eae and prevalence of the five major serogroups}

Real-time PCRs enabled detection of stx genes from enrichment broths of 44 shellfish batches (34.9\%), 107 water samples (91.4\%) and 11 sediment samples (28.2\%) (Table 1). In correlation with the level of contamination of shellfish, stx genes were more frequently detected from cockles and mussels (50.0\% and 36.5\% stx ${ }^{+}$, respectively) than from oysters (22\%). The presence of stx gene was previously investigated in shellfish batches collected between 2002 and 2004 from across France (Gourmelon et al. 2006). In this earlier study, in which 72 samples of mussels (41) oysters (27) and cockles (4) were analyzed, the stx gene was also more frequently detected from cockles (100\%) than from mussels (43.9\%) or oysters (33.3\%). The stx2 gene was slightly more frequently found than stx1 in enrichment broths from water and sediments, while stx 1 was more frequently detected from shellfish. As with stx, eae gene was more frequently detected in water than in shellfish or sediments. Indeed, 116 water samples (99.1\%), 92 shellfish batches (73.0\%), and 19 sediments (48.7\%) were 
$e a e^{+}$(Table 1). eae was more frequently detected in cockles and mussels (87.5\% and $82.7 \%$, $e a e^{+}$, respectively) than in oysters $\left(56.0 \% e^{e a e^{+}}\right)$. A total of 152 samples (37 shellfish, 107 waters, and 8 sediments) were positive for at least one stx gene and the eae gene. Real-time PCRs were performed to detect genetic markers associated with the five major serogroups from the 152 corresponding enrichment broths (Table 2). One or several serogroups were detected from 28 samples of shellfish, 106 waters and 7 sediments. Consequently, $22.2 \%$ of shellfish samples, $90.6 \%$ of water samples and $17.9 \%$ of sediment samples were positive for stx, eae and one of the O-group markers, with a higher percentage of positive samples among environmental water samples than among cattle faeces collected at slaughterhouse (58\% in cattle faeces [Bibbal et al. 2014]). Regardless of the sample type, serogroups O103 and O145, followed by $\mathrm{O} 26$ and $\mathrm{O} 157$ were the most frequently detected.

\section{Isolation and characterization of strains belonging to serogroup $0157,026,0103,0111$} or 0145

Ten strains (five from water and five from shellfish) were isolated using two complementary methods: direct streaking and IMS (Immuno-Magnetic Separation). Their characterization revealed that six belonged to the O26:H11 serotype, while two were identified as O103:H2 and two as O145:H28 (Table 3); all 10 isolates contained the eae gene. These strains were isolated from highly contaminated samples (E. coli geometric mean of 14,550 per $100 \mathrm{~g}$ for shellfish and 4,490 per $100 \mathrm{ml}$ for waters). Only one strain possessed a stx gene (stx1) whereas the remaining corresponded to potentially enteropathogenic E. coli (EPEC). The STEC strain belonged to the O26:H11 serotype and was isolated from mussels. Only 9 of the 141 enrichment broths that were positive for stx, eae and one of the major serotypes (6\%) resulted in STEC or EPEC isolation. We have to consider the possibility that the targeted stx, 
eae and serotypes markers could also be detected in the absence of culturable STECs. Indeed, their detection can be due to the presence free bacteriophages, dead or viable but nonculturable bacteria, or other bacteria such as Shigella and Citrobacter, which are also known to carry these genes (Muniesa et al. 1999; Martinez-Castillo et al. 2013). A poor isolation rate of highly pathogenic STEC was also previously described for other matrices, such as cattle faeces (Bibbal et al. 2014), retail-minced beef (Auvray et al. 2007) and raw-milk cheeses (Madic et al. 2011) from which six $(n=150)$, zero $(n=164)$ and zero $(n=400)$ strains were isolated, respectively. In the present study, EPEC were more frequently isolated than STEC. This may be the consequence of the loss of stx genes by STEC discharged in the environment. Indeed, previous studies have demonstrated the capacity of STEC to lose stx genes in bovine, avian human and environmental sources (Feng et al. 2001; Wetzel and LeJeune 2007).

A low detection rate of STEC in shellfish is in agreement with previous studies. Indeed, three studies previously described STEC belonging to the O157-serogroup in shellfish using an immunomagnetic method. One, conducted in France on 150 oyster samples, led to the isolation of only one O157-E. coli strain (O157:H- stx1 $1^{+}$, stx $2 c^{+}$, eae $)$(Guyon et al. 2000), a second failed to isolate O157:H7 strains from 192 batches of different shellfish species in the UK (MacRae et al. 2005) and the third described the isolation of one EPEC strain (O157:H7) from 72 shellfish batches collected in France (Gourmelon et al. 2006). Other approaches focused on the isolation of $E$. coli strains followed by investigation for the presence of stx genes, which demonstrated low percentages of STEC among the isolates $(6.2 \%$ in shellfish from Morocco [Bennani et al. 2011] and 4.1\% in clams from India [Sanath Kumar et al. 2001]). Furthermore, five STEC strains not belonging to the five major serogroups have previously been isolated in France from shellfish by analyzing STEC by hybridization, following culture enrichment (Gourmelon et al. 2006). 
These results suggest that STEC and EPEC are occasionally present in the environment and can contaminate shellfish. According to our results, the risk of human infection by highly pathogenic STEC resulting from the consumption of shellfish from the investigated areas seems to be limited as only one STEC strain was isolated from 126 batches taken from the area and shellfish which are from category B or C areas, which are depurated or which undergo protracted relaying prior to sale. As with the E. coli indicators, we may expect STEC to be eliminated during the depuration or relaying step. However, further assays are currently being undertaken in our laboratory to compare STEC behavior with that of E. coli indicators in shellfish.

\section{CONCLUSION}

In conclusion, this study shows that the ISO/TS-13136 protocol effectively detects STEC or EPEC strains belonging to the five major serotypes in shellfish and environmental samples. Even though stx and eae genes were often detected, the presence of STEC in such environments appears to be limited, as only one STEC and nine EPEC were isolated from water or shellfish samples. Furthermore, the human health risk associated with consuming the shellfish collected from these sites should be reduced as they are depurated or relayed prior to consumption.

\section{MATERIALS AND METHODS}

\section{Origin and collection of samples}

Three French shellfish sites from the English Channel coastal area were studied. One is located in the "Cotes d'Armor" department (Brittany region) while others are in the department "La Manche” (Lower-Normandy region). All three sites are characterised as 
receiving inputs from agricultural catchments with high stocking densities (cattle, sheep, pigs, or poultry) but are also impacted by microbial pollution of human origin. The bays are the focus of extensive shellfish gathering activities. According to the European classification of shellfish harvesting areas (Anonymous 2004), these shellfish sites are classified as category B (E. coli $<4,600$ CFU per $100 \mathrm{~g}$ total flesh for $90 \%$ of the samples) for mussels and oysters and as category C (E. coli <46,000 CFU per 100 g) for cockles. Shellfish from category B areas are only suitable for human consumption following depuration, relaying or cooking by an approved method whereas shellfish from category C areas can only be consumed after relaying for at least two months or cooking by an approved method. For each site, mussels, oysters and cockles were collected monthly, from February 2013 to February 2014. A total of

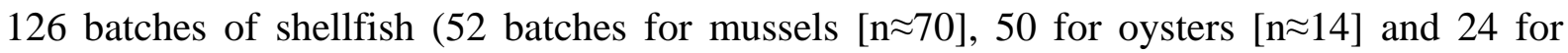
cockles $[\mathrm{n} \approx 80])$ were analysed. In parallel, 117 water samples from nine different points located upstream of the shellfish areas and 39 samples of sediment were collected. Samples, which were transported in insulated cooler boxes, were analysed within 24h. Before analysis, shellfish were scrubbed under running tap water to remove debris and algae.

\section{E. coli enumeration}

E. coli enumeration was performed using the Most Probable Number method in MUGmicrotitre plates according to the EN/ISO-9308-3 method (Anon 1998) and using an impedance method according to NF/V-08-106 for shellfish (Anon 2000).

\section{E. coli enrichment}

After opening, shellfish were crushed in a Warring blender for 60 seconds. Twenty-five grammes of crushed flesh and intravalvular liquid were introduced into $225 \mathrm{ml}$ of buffered peptone water (BPW). For sediment, $10 \mathrm{~g}$ were introduced into the same quantity of BPW 
while for water samples, 1 litre was filtered using $0.45 \mu \mathrm{m}$ membranes and the filter placed in $225 \mathrm{ml}$ of BPW. Incubation was performed at $37^{\circ} \mathrm{C}$, for $24 \mathrm{~h}$.

\section{Detection of stx and eae genes and markers associated with the five major serotypes}

DNA was extracted from $1 \mathrm{~mL}$ of enrichment cultures in BPW using an automatic method (EZ1-biorobot, and DNA tissue card kit [Qiagen ${ }^{\circledR}$, Cournaboeuf, France ]). stx and eae genes were detected by real-time PCR, according to ISO/TS-13136. For samples positive for stx and eae, genetic markers associated with the major serogroups $\mathrm{O} 157, \mathrm{O} 26, \mathrm{O} 103, \mathrm{O} 111$, and O145 (rfbEO157, wzxO26, wzxO103, wbd1O111, and ihp1O145 genes, respectively) were detected by real-time PCR, also according to ISO/TS-13136 and using primers and probes published previously (Nielsen and Andersen 2003; Perelle et al. 2007).

\section{Isolation of Shiga toxin-producing $E$. coli}

The isolation of STEC strains was performed only for the positive samples for which the targeted combination of genetic marker was detected, i.e., stx, eae and at least one $\mathrm{O}$ group marker. From the positive BPW broths, direct streaking and streaking after immuno-magnetic separation (IMS), were performed on the following media. The O157 serogroups were searched by direct streaking onto chromIDTM $0157: H 7+$ cefixime-tellurite (BioMérieux ${ }^{\circledR}$ ) and streaking after the IMS onto cefixime-tellurite-Sorbitol-MacConkey agar (biokar, Beauvais, France) and chromID ${ }^{\mathrm{TM}} \mathrm{O} 157$ (bioMérieux, Marcy l’Etoile, France). Streakings for O26 serogroups were performed onto Sorbitol-MacConkey agar (SMAC) (bioMérieux, Marcy l'Etoile, France) and after onto SMAC and chromID ${ }^{\mathrm{TM}}$ O26 (bioMérieux, Marcy l'Etoile, France) after the IMS, while serogroups O103, O145 and O111 were directly detected using Posse media (Posse et al. 2008) or using SMAC and chromID ${ }^{\mathrm{TM}}$ after the IMS. All media were incubated for 18 to $24 \mathrm{~h}$ at $37^{\circ} \mathrm{C}$. Confirmation of the clones belonging to a particular 
serotype and presence of stx and/or eae genes were then tested by PCR on presumptive colonies as described in ISO/TS-13136. Characterization of the fliCH alleles (fliCH2, fliCH7, fliCH8, fliCH11, and fliCH28) was investigated by PCR, as described by Madic et al. (2011).

\section{ACKNOWLEDGMENTS}

This work was funded by the European Regional Development Fund Interreg IVA Programme as part of the collaborative project RiskManche. Charlotte Balière was supported by a grant from Ifremer and Agence de l'Eau Loire-Bretagne. We thank Clémence Balière and Quentin Bruey, for their participation in the sampling and technical assistance and Huw Taylor for his critical review of the manuscript.

\section{CONFLICT OF INTEREST}

No conflict of interest declared

\section{REFERENCES}

Anon. (1998) ISO 9308-3 Water quality - Detection and enumeration of Escherichia coli and coliform bacteria in surface and waste water - Part 3: Miniaturized method (Most Probable Number) by inoculation in liquid medium. ISO, $20 \mathrm{p}$.

Anon. (2000) NF V 08-600 Microbiologie des aliments - Dénombrement des Escherichia coli présumés dans les coquillages vivants - Technique du nombre le plus propable (Microbiologie of Foods and Foodstuffs Products - Enumeration of Presumptive Escherichia coli in Living Shellfish - MPN Technique). AFNOR, 16 p.

Anonymous. (2004) Regulation (EC) No 854/2004 of the European parliament and of the council of 29 April 2004 laying down specific rules for the organisation of official controls on products of animal origin intended for human consumption. 
Auvray, F., Lecureuil, C., Taché, J., Leclerc, V., Deperrois, V. and Lombard, B. (2007) Detection, isolation and characterization of Shiga toxin-producing Escherichia coli in retailminced beef using PCR-based techniques, immunoassays and colony hybridization. Lett Appl Microbiol 45, 646-651

Bennani, M., Badri, S., Baibai, T., Oubrim, N., Hassar, M., Cohen, N. and Amarouch, H. (2011) First detection of Shiga toxin-producing Escherichia coli in shellfish and coastal environments of Morocco. Appl Biochem Biotechnol 165, 290-299.

Beutin, L. and Fach, P. (2014) Detection of Shiga toxin-producing Escherichia coli from nonhuman sources and strain typing. Microbiology Spectrum 2(4):EHEC-0001-2013.

Bibbal, D., Loukiadis, E., Kérourédan, M., Peytavin de Garam, C., Ferré, F., Cartier, P., Gay, E., Oswald, E., Auvray, F. and Brugère, H. (2014) Intimin gene (eae) subtype-based real-time PCR strategy for specific detection of Shiga toxin-producing Escherichia coli serotypes O157:H7, O26:H11, O103:H2, O111:H8, and O145:H28 in cattle feces. Appl Environ Microbiol 80, 1177-1184.

DGAL. Direction générale de l'alimentation. (2013) Plans de surveillance-Plan de contrôle, Bilan 2012. Ministère de l'agriculture, de l'agroalimentaire et de la fôret. Octobre.

EFSA. European Food Safety Authority. (2009) Technical specifications for the monitoring and reporting of verotoxigenic Escherichia coli (VTEC) on animals and food (VTEC surveys on animals and food). EFSA J.7:1366-1409.http://dx.doi.org/10.2903/j.efsa.2009.1366.

Feng, P., Dey, M., Abe, A. and Takeda, T. (2001) Isogenic strain of Escherichia coli O157:H7 that has lost both Shiga toxin 1 and 2 Genes. ASM 8, 711-717.

Gyles, C.L. (2007) Shiga toxin-producing Escherichia coli: an overview. J Anim Sci 85, 4562.

Gourmelon, M., Montet, M.P., Lozach, S., Le Mennec C., Pommepuy, M., Beutin, L. and Vernozy-Rozand, C. (2006) First isolation of Shiga toxin 1d producing Escherichia coli variant strains in shellfish from coastal areas in France. J Appl Microbiol 100, 85-97.

Guyon, R., Dorey, F., Collobert, J.F., Foret, J., Goubert, C., Mariau, V. and Malas, J.P. (2000) Detection of shiga toxin-producing Escherichia coli O157 in shellfish (Crassostrea gigas). Sci Aliment 20, 457-466.

ISO. (2012) ISO/TS-13136:2012: Microbiology of food and animal feed. Real-time polymerase chain reaction (PCR)-based method for the detection of food-borne pathogens. Horizontal method for the detection of Shiga toxin-producing Escherichia coli (STEC) and the determination of O157, O111, O26, O103 and O145 serogroups. International Organization for Standardization, Geneva, Switzerland.

Loukiadis, E., Kérourédan, M., Beutin, L., Oswald, E. and Brugère, H. (2006) Characterization of Shiga toxin gene (stx)-positive and intimin gene (eae)-positive Escherichia coli isolates from wastewater of slaughterhouses in France. Appl Environ Microbiol 72, 3245-3251. 
MacRae, M., Hamilton, C., Strachan, N.J., Wright, S. and Ogden, I.D. (2005) The detection of Cryptosporidium parvum and Escherichia coli $\mathrm{O} 157$ in UK bivalve shellfish. J Microbiol Methods 60, 395-401.

Madic, J., Vingadassalon, N., De Garam, C.P., Marault, M., Scheutz, F., Brugère, H., Jamet, E. and Auvray, F. (2011) Detection of Shiga toxin-producing Escherichia coli serotypes O26:H11, O103:H2, O111:H8, O145:H28, and O157:H7 in raw-milk cheeses by using multiplex real-time PCR. Appl Environ Microbiol 77, 2035-2041.

Martinez-Castillo, A., Quirós, P., Navarro, F., Miró, E. and Muniesa, M. (2013) Shiga toxin 2-encoding bacteriophages in human fecal samples from healthy individuals. Appl Environ Microbiol 79, 4862-4868.

Muniesa, M., Lucena, F. and Jofre, J. (1999) Study of the potential relationship between the morphology of infectious somatic coliphages and their persistence in the environment. $J$ Appl Microbiol 87, 402-409.

Nielsen, E.M. and Andersen, M.T. (2003) Detection and characterization of Verocytotoxinproducing Escherichia coli by automated 5' nuclease PCR Assay. J. Clin. Microbiol 41, 28842893.

O'Brien, A.D., Newland, J.W., Miller, S.F., Holmes, R.K., Smith, H.W. and Formal, S.B. (1984) Shiga-like toxin-converting phages from Escherichia coli strains that cause hemorrhagic colitis or infantile diarrhea. Science 226, 694-696.

Ogden, L.D., Fenlon, D.R., Vinten, A.J. and Lewis, D. (2001) The fate of Escherichia coli O157 in soil and its potential to contaminate drinking water. Int J Food Microbiol 66, 111117.

Paton, J.C. and Paton, A.W. (1998) Pathogenesis and diagnosis of Shiga toxin-producing Escherichia coli infections. Clin Microbiol Rev 11, 450-479.

Perelle, S., Dilasser, F., Grout, J. and Fach, P. (2007) Screening food raw materials for the presence of the world's most frequent clinical cases of Shiga toxin-encoding Escherichia coli O26, O103, O111, O145 and O157. Int J Food Microbio 113, 284-288.

Posse, B., De Zutter, L., Heyndrickx, M. and Herman, L. (2008) Novel differential and confirmation plating media for Shiga toxin-producing Escherichia coli serotypes O26, O103, O111, O145 and sorbitol-positive and -negative O157. FEMS Microbiol Lett 282, 124-131.

Potasman, I., Paz, A. and Odeh, M. (2002) Infectious outbreaks associated with bivalve shellfish consumption: a worldwide perspective. Clin Infect Dis 35, 921-928.

Pradel, N., Livrelli, V., Champs, C.D., Palcoux, J.-B., Reynaud, A., Scheutz, F., Sirot, J., Joly, B. and Forestier, C. (2000) Prevalence and characterization of Shiga toxin-producing Escherichia coli isolated from cattle, food, and children during a one-year prospective study in France. J. Clin. Microbiol 38, 1023-1031. 
Sanath Kumar H., Otta, S.K. and Karunasagar, I. (2001) Detection of Shiga-toxigenic Escherichia coli (STEC) in fresh seafood and meat marketed in Mangalore, India by PCR. Lett Appl Microbiol 33, 334-338.

Vernozy-Rozand, C., Montet, M.P., Lequerrec, F., Serillon, E., Tilly, B., Bavai, C., RayGueniot, S., Bouvet, J., Mazuy-Cruchaudet, C. and Richard, Y. (2002) Prevalence of Verotoxin-producing Escherichia coli (VTEC) in slurry, farmyard manure and sewage sludge in France. J Appl Microbiol 93, 473-478.

Wetzel, A.N. and LeJeune, J.T. (2007) Isolation of Escherichia coli O157:H7 strains that do not produce Shiga toxin from bovine, avian and environmental sources. Lett Appl Microbiol 45, 504-507.

\section{TABLES}

Table 1. Prevalence of stx1, stx2 and eae genes in enrichment broths.

\begin{tabular}{lccccr}
\hline Sample (n) & $\begin{array}{c}s t x 1^{*} \\
\mathrm{n}(\%)\end{array}$ & $\begin{array}{c}s t x 2^{\dagger} \\
\mathrm{n}(\%)\end{array}$ & $\begin{array}{c}s t x 1 \text { and } \\
\text { stx2 } \\
\mathrm{n}(\%)\end{array}$ & $\begin{array}{c}\text { Total } s t x 1 \\
\text { and/or } s t x 2 \mathrm{n} \\
(\%)\end{array}$ & $\begin{array}{c}\text { eae } \\
\mathrm{n}(\%)\end{array}$ \\
\hline Cockles (24) & $3(12.5)$ & $3(12.5)$ & $6(25.0)$ & $12(50.0)$ & $21(87.5)$ \\
Mussels (52) & $12(23.1)$ & $8(15.4)$ & $1(1.9)$ & $21(40.4)$ & $43(82.7)$ \\
Oysters (50) & $7(14.0)$ & $2(4.0)$ & $2(4.0)$ & $11(22.0)^{\ddagger}$ & $28(56.0)^{\S}$ \\
Total Shellfish (126) & $22(17.5)$ & $13(10.3)$ & $9(7.1)$ & $44(34.9)$ & $92(73.0)$ \\
Waters (117) & $10(8.5)$ & $21(17.9)$ & $76(65.0)$ & $107(91.4)^{ף}$ & $116(99.1)^{* *}$ \\
Sediment (39) & $3(7.7)$ & $6(13.4)$ & $2(5.1)$ & $11(28.2)$ & $19(48.7)$
\end{tabular}


Table 2. Prevalence of strains of the five highly pathogenic serogroups in the BPW broths

372 and number of isolated strains belonging to the STEC or EPEC pathotype.

\begin{tabular}{|c|c|c|c|c|c|c|c|c|}
\hline Sample (n) & $\begin{array}{l}s t x^{+} \\
\text {and } \\
e a e^{+}\end{array}$ & $\begin{array}{l}\mathrm{O} 157^{+} \\
(\%)^{*}\end{array}$ & $\begin{array}{l}\mathrm{O}^{+} 6^{+} \\
(\%)^{*}\end{array}$ & $\begin{array}{l}\mathrm{O} 103^{+} \\
(\%)^{*}\end{array}$ & $\begin{array}{l}\mathrm{O} 111^{+} \\
(\%)^{*}\end{array}$ & $\begin{array}{l}\mathrm{O} 145^{+} \\
(\%)^{*}\end{array}$ & $\begin{array}{l}s t x^{+}, e a e^{+} \\
\text {and } \\
\text { serotype } \\
(\%)^{\ddagger}\end{array}$ & $\begin{array}{l}\text { isolated } \\
\text { strains }\end{array}$ \\
\hline $\begin{array}{l}\text { Shellfish } \\
\text { (126) }\end{array}$ & 37 & $\begin{array}{r}7 \\
(18.9)\end{array}$ & $\begin{array}{r}13 \\
(35.1)\end{array}$ & $\begin{array}{r}20 \\
(54.1)\end{array}$ & $\begin{array}{r}3 \\
(8.1)\end{array}$ & $\begin{array}{r}15 \\
(40.5)\end{array}$ & $\begin{array}{r}28 \\
(22.2)\end{array}$ & 5 \\
\hline $\begin{array}{l}\text { Waters } \\
\text { (117) }\end{array}$ & 107 & $\begin{array}{r}65 \\
(60.7)\end{array}$ & $\begin{array}{r}67 \\
(62.6)\end{array}$ & $\begin{array}{r}93 \\
(86.9)\end{array}$ & $\begin{array}{r}30 \\
(28.0)\end{array}$ & $\begin{array}{r}83 \\
(77.6)\end{array}$ & $\begin{array}{r}106 \\
(90.6)^{\S}\end{array}$ & 5 \\
\hline $\begin{array}{l}\text { Sediment } \\
\text { (39) }\end{array}$ & 8 & $\begin{array}{r}1 \\
(12.5)\end{array}$ & $\begin{array}{r}1 \\
(12.5)\end{array}$ & $\begin{array}{r}5 \\
(65.5)\end{array}$ & $\begin{array}{r}0 \\
(0.0)\end{array}$ & $\begin{array}{r}4 \\
(50.0)\end{array}$ & $\begin{array}{r}7 \\
(17.9)\end{array}$ & 0 \\
\hline
\end{tabular}

373

${ }^{*} \%$ calculated based on the number of samples $s x^{+}$and $e a e^{+}$.

${ }^{\dagger} s t x^{+}, e a e^{+}$and at least one of the major serotypes

$\ddagger$ \% calculated based on total number of samples.

$\S \mathrm{P}$ value (Khi2 test) between waters and other samples $=1.62 \times 10^{-30}$

Table 3. Characterisation of STEC and EPEC strains isolated from shellfish and water.

\begin{tabular}{|c|c|c|c|c|c|}
\hline Strain & Sample type & E. coli count & Serotype & stx (type) & eae \\
\hline 10 & Mussel & $15,000^{*}$ & O26:H11 & $+(s t x 1)$ & + \\
\hline 9 & Cockle & $12,000^{*}$ & O26:H11 & - & + \\
\hline 7 & Mussel & $15,000^{*}$ & O26:H11 & - & + \\
\hline 4 & Water & $3,570^{\dagger}$ & O26:H11 & - & + \\
\hline 5 & Water & $5,200^{\dagger}$ & O26:H11 & - & + \\
\hline 8 & Water & $16,620^{\dagger}$ & O26:H11 & - & + \\
\hline 2 & Cockle & $22,000^{*}$ & O145:H28 & - & + \\
\hline 3 & Mussel & $11,000^{*}$ & O145:H28 & - & + \\
\hline 1 & Water & $357^{\dagger}$ & O103:H2 & - & + \\
\hline 6 & Water & $16,620^{\dagger}$ & O103:H2 & - & + \\
\hline
\end{tabular}

